\title{
PENGGUNAAN MEDIA ANIMASI DALAM PEMBELAJARAN TRIGONOMETRI UNTUK MENINGKATKAN HASIL BELAJAR MAHASISWA TADRIS MATEMATIKA IAIN WALISONGO SEMARANG
}

\author{
Emy Siswanah
}

\begin{abstract}
Abstrak
Trigonometri merupakan pelajaran yang bersifat abstrak. Agar materi yang bersifat abstrak menjadi mudah dipahami diperlukan suatu media pembelajaran. Salah satu media pembelajaran yang dapat diterapkan dalam pembelajaran trigonometri adalah media animasi. Efek animasi pada media animasi membuat media tersebut menjadi lebih menarik sehingga mampu menarik perhatian mahasiswa. Pemanfaatan media animasi dalam pembelajaran dapat membangkitkan keinginan, minat, serta meningkatkan motivasi mahasiswa. Penggunaan media animasi mampu merangsang kegiatan belajar mahasiswa, membantu keefektifan proses pembelajaran, memperlancar pencapaian tujuan untuk memahami dan mengingat informasi yang diberikan. Selain itu, penggunaan media animasi juga dapat menjelaskan materi yang bersifat abstrak menjadi konkret sehingga membantu mahasiswa dalam memahami pelajaran trigonometri. Hal ini berakibat pada meningkatnya hasil belajar mahasiswa pada kelas yang pembelajarannya menggunakan media animasi. Dengan demikian penggunaan media animasi dapat meningkatkan hasil belajar mahasiswa Tadris Matematika IAIN Walisongo Semarang.
\end{abstract}

Kata Kunci : media animasi, trigonometri, hasil belajar 


\section{PENDAHULUAN}

Trigonometri merupakan mata kuliah yang terdapat pada semester II. Mata kuliah ini bersifat abstrak sehingga mahasiswa perlu memahami secara mendalam agar konsep trigonometri dapat dicerna. Ilmu matematika bersifat hierarki atau berjenjang, artinya konsep pada materi sebelumnya akan menjadi dasar untuk materi selanjutnya. Selain itu, tingkatan materi juga semakin abstrak. Oleh karena itu, trigonometri menjadi mata kuliah yang sangat penting untuk dipelajari dan dikuasai karena mata kuliah ini merupakan mata kuliah yang menjadi dasar mata kuliah keahlian pada semester berikutnya. Jika mahasiswa mengalami kesulitan dalam mempelajari trigonometri maka mahasiswa akan semakin sulit untuk mempelajari mata kuliah semester selanjutnya. Hal ini juga akan berdampak pada mahasiswa semester tinggi yang akan menempuh praktik pengalaman lapangan. Selain itu, juga berdampak pada lulusan sebagai calon guru matematika yang nantinya akan mengajarkan trigonometri karena trigonometri terdapat dalam kurikulum SMA/MA/SMK.

Agar pembelajaran trigonometri yang bersifat abstrak menjadi mudah dipahami mahasiswa maka diperlukan suatu media pembelajaran yang menarik. Media pembelajaran dapat mengubah sesuatu yang abstrak menjadi konkret dan yang kompleks menjadi sederhana. Penggunaaan media pembelajaran akan sangat membantu proses belajar mengajar sehingga tercipta pembelajaran yang berkualitas. Media pembelajaran yang saat ini telah berkembang demikian pesat adalah media animasi. Contoh-contoh media animasi yang dapat digunakan sebagai media pembelajaran matematika diantaranya adalah media animasi berbasis java, media animasi berbasis flash, dan media animasi math open references.

Penggunaan media animasi diharapkan mampu membangkitkan motivasi dan rangsangan kegiatan belajar mahasiswa, membantu keefektifan proses pembelajaran, menarik dan mengarahkan perhatian mahasiswa untuk berkonsentrasi kepada isi pelajaran, memperlancar pencapaian tujuan untuk memahami dan mengingat informasi yang diberikan, pembelajaran menjadi lebih menarik, membawa kesegaran dan variasi baru bagi pengalaman belajar ma- 
hasiswa sehingga mahasiswa tidak bosan dan tidak bersikap pasif.

Dalam penelitian akan dibahas apakah penggunaan media animasi dalam pembelajaran trigonometri dapat meningkatkan hasil belajar mahasiswa tadris matematika. Penelitian ini difokuskan pada penggunaan media animasi pada mata kuliah trigonometri, bab Segitiga yang meliputi Aturan Sinus, Aturan Cosinus, dan Luas Segitiga. Objek penelitian ini dibatasi pada mahasiswa semester II Tadris Matematika IAIN Walisongo yang pada semester ini akan menempuh mata kuliah trigonometri. Pada penelitian ini hasil belajar yang akan menjadi fokus penelitian dibatasi hanya pada ranah kognitif saja. Menurut Schramm (Sadiman, 2003), “media pembelajaran adalah teknologi pembawa pesan (informasi) yang dapat dimanfaatkan untuk keperluan pembelajaran". Sedangkan Sadiman (2003) menjelaskan bahwa "media pembelajaran adalah segala sesuatu yang dapat digunakan untuk menyalurkan pesan dari pengirim ke penerima, sehingga dapat merangsang pikiran, perasaan, perhatian dan minat siswa sehingga proses belajar terjadi". "Media dalam konteks belajar dan pembelajaran dapat diartikan sebagai segala sesuatu yang dapat menyalurkan pesan atau materi ajar dari guru sebagai komunikator kepada siswa sebagai komunikan dan sebaliknya" (Ginting, 2007).

Pada proses pembelajaran, seorang pendidik harus dapat menguasai dan memilih media pembelajaran yang tepat untuk digunakan pada proses pembelajaran. Hal tersebut bertujuan agar materi pembelajaran yang diberikan akan diterima dengan baik oleh siswa, sehingga proses pembelajaran akan berlangsung efektif. Sebagaimana dipaparkan oleh Sudjana dan Rivai (2011) "penggunaan media pengajaran dalam proses pengajaran sangat dianjurkan untuk mempertinggi kualitas pengajaran". Kemudian ditambahkan oleh Susilana dan Riyana (2008) bahwa "dalam bentuk komunikasi pembelajaran manapun sangat dibutuhkan peran media untuk lebih meningkatkan tingkat keefektifan pencapaian tujuan/kompetensi. Artinya, proses pembelajaran tersebut akan terjadi apabila ada komunikasi antara penerima pesan dengan sumber/penyalur pesan lewat media tersebut".

Berbagai inovasi pembelajaran dengan upaya perluasan bahan 
ajar telah memposisikan teknologi ICT sebagai alat yang memberikan kontribusi yang positif dalam proses pembelajaran, khususnya pembelajaran matematika. Selama beberapa tahun terakhir, terobosan besar telah dibuat dalam memanfaatkan komputer untuk membantu proses pembelajaran. Hal ini, dikombinasikan dengan akses kecepatan tinggi ke internet telah membuka peluang baru dalam pendidikan. Dalam mengintegrasikan teknologi ke dalam proses pembelajaran, teknologi ICT berperan pada menciptakan kondisi belajar yang menyenangkan dan mengasyikan (efek emosi). Salah satu media ICT yang dapat digunakan dalam pembelajaran adalah media animasi. Dengan bantuan kecanggihan teknologi, para peneliti telah banyak membuat media pembelajaran yang berbentuk animasi. Media animasi tersebut berbentuk java atau flash yang dihasilkan dari berbagai macam software.

Media animasi adalah hasil teknologi modern yang membuka kemungkinan-kemungkinan yang besar sebagai alat pendidikan (Nasution, 1999). Menurut Latuheru (1988) "penggunaan animasi dengan bantuan komputer sebagai media pembelajaran memiliki banyak kelebihan dan dapat menambah kesan realisme". Penggunaan animasi tidak terlepas pada peran alat bantu komputer. Animasi dapat diperoleh melalui grafiks tiga dimensi atau dua dimensi. Animasi merupakan gerakan objek maupun teks yang diatur sedemikian rupa sehingga kelihatan menarik dan kelihatan lebih hidup. Menurut Utami (2007), “animasi adalah rangkaian gambar yang membentuk sebuah gerakan. Media animasi dapat menunjukkan urutan dari waktu ke waktu seperti sebuah proses". Salah satu keunggulan animasi adalah kemampuannya untuk menjelaskan suatu kejadian secara sistematis dalam tiap waktu perubahan. Hal ini sangat membantu dalam menjelaskan prosedur dan urutan kejadian. Sehingga dapat diartikan media animasi merupakan media yang dapat digunakan dalam proses pembelajaran.

\section{METODE}

Populasi adalah keseluruhan subjek penelitian" (Arikunto, 2010). Populasi dalam penelitian ini adalah seluruh mahasiswa Semester II Tadris Matematika IAIN Walisongo Semarang Tahun Aka- 
demik 2012/ 2013 yang berjumlah 64 mahasiswa. Mahasiswa Semester II Tadris Matematika terbagi menjadi 2 kelas yaitu TM-2A dan TM-2B yang masing-masing berjumlah 32 mahasiswa.

Sudjana (2005) menyatakan bahwa "sampel adalah sebagian dari populasi terjangkau yang memiliki sifat sama dengan populasi". Sampel dalam penelitian ini ditentukan dengan menggunakan cluster random sampling, yaitu teknik pengambilan sampel secara acak dengan cara mengambil suatu kelompok atau kelas dari anggota populasi di antara kelas-kelas homogen. Kelas yang diambil akan menjadi kelas eksperimen dan kelas kontrol. Karena mahasiswa Tadris Matematika semester II berjumlah 64 mahasiswa maka seluruh populasi akan dijadikan sampel penelitian.

Penelitian yang akan dilaksanakan merupakan penelitian kuantitatif. Jenis penelitian ini adalah penelitian eksperimen. Pada penelitian ini terdapat dua kelas yang dijadikan objek penelitian, yaitu kelas eksperimen dan kelas kontrol. Pada kelas eksperimen pembelajaran dilaksanakan dengan menggunakan media animasi dan pada kelas kontrol pembelajaran dilaksanakan tanpa menggunakan media animasi.

Desain penelitian yang akan dilaksanakan dapat dijelaskan melalui tabel 1.

Tabel 1. Desain Penelitian

\begin{tabular}{|c|c|c|c|}
\hline Kelas & Pretest & Perlakuan & Posttest \\
\hline E & X & A & Y \\
\hline C & X & B & Y \\
\hline
\end{tabular}

(Sudjana dan Ibrahim, 1989)

Keterangan:

E : Kelas Eksperimen

C : Kelas Kontrol

A : Pembelajaran menggunakan media animasi

B : Pembelajaran tanpa menggunakan media animasi

Penelitian ini dilakukan dalam tiga tahap meliputi tahap persiapan, tahap pelaksanaan dan tahap analisis data.

1. Tahap persiapan 
a) Penyusunan perangkat pembelajaran antara lain SAP, Lembar Kerja Siswa, dan tugas-tugas yang akan diberikan kepada mahasiswa.

b) Penyusunan instrumen penelitian

c) Uji coba instrumen/perangkat tes. Instrumen yang telah diujicobakan kemudian dihitung validitas, reliabilitas, tingkat kesukaran soal, dan daya beda.

2. Tahap pelaksanaan

Penelitian ini dilaksanakan di prodi Tadris Matematika Fakultas Tarbiyah IAIN Walisongo. Penelitian ini melibatkan dua kelas yaitu kelas yang pembelajarannya menggunakan media animasi (kelas eksperimen) dan kelas yang pembelajarannya dilakukan tanpa menggunakan media animasi (kelas kontrol).

3. Analisis Data

Analisis data meliputi analisis data populasi, analisis tahap awal, dan analisis tahap akhir. Pada analisis data populasi, analisis tahap awal dilakukan uji normalitas, uji homogenitas, dan uji-t. Pada analisis tahap akhir dilakukan uji ANCOVA. Uji normalitas menggunakan uji Kolmogorov-Smirnov dan uji homogenitas menggunakan uji Levene. Perhitungan uji normalitas, uji homogenitas, uji kesamaan dua rata-rata, dan uji ANCOVA dilakukan menggunakan SPSS.

\section{HASIL PENELITIAN DAN PEMBAHASAN}

\section{Hasil Penelitian}

\section{Analisa Data Populasi}

\section{Uji Normalitas}

Berdasarkan hasil output SPSS diperoleh nilai signifikansi untuk kelas TM-2A dan kelas TM-2B masing-masing adalah 0.200 . Karena nilai signifikasi kelas TM-2A dan kelas TM-2B masing-masing > 0.05 maka $\mathrm{H}_{0}$ diterima. Jadi, kelas TM-2A dan kelas TM-2B berdistribusi normal sehingga uji selanjutnya menggunakan statistik parametrik.

\section{Uji Homogenitas}

Perhitungan SPSS untuk uji homogenitas diperoleh nilai

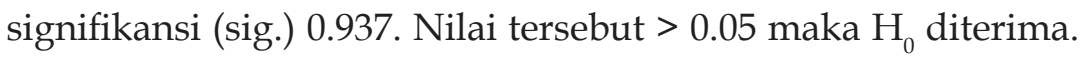


Hal ini berarti populasi mempunyai varians yang sama.

3. Uji Kesamaan Keadaan Awal Populasi (Uji Kesamaan Dua Rata-Rata)

Berdasarkan hasil output SPSS untuk independent samples tes di atas, diperoleh $t=0.067$ dengan Sig. $=0.947$ (karena data homogen yang dilihat adalah pada Equal Variances Assumed). Dari hasil output tersebut dapat disimpulkan bahwa $\mathrm{H}_{0}$ diterima yang berarti nilai rata-rata IPK kedua kelas populasi adalah sama.

\section{Analisa Tahap Awal}

Analisa data tahap awal adalah analisa data nilai pretest materi pokok Segitiga.

\section{Uji Normalitas}

Dari hasil output SPSS diperoleh nilai signifikasnsi untuk kelas ekaperimen adalah 0,108 dan kelas kontrol adalah 0.167. Karena nilai signifikasi kelas eksperimen dan kelas kontrol mas-

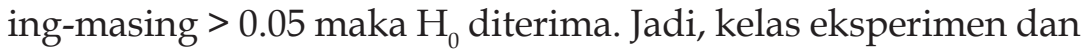
kelas kontrol berdistribusi normal.

\section{Uji Homogenitas}

Berdasarkan data output SPSS untuk uji homogenitas diperoleh nilai signifikansi (sig.) 0.893 . Nilai tersebut $>0.05$ maka $\mathrm{H}_{0}$ diterima. Hal ini berarti kedua kelas sampel mempunyai varians yang sama.

\section{Uji Kesamaan Dua Rata-Rata}

Berdasarkan hasil output SPSS untuk independent samples tes di atas, diperoleh $t=-0,290$ dengan Sig $=0.772$ (karena data homogen yang dilihat adalah pada Equal Variances Assumed). Dari hasil output tersebut dapat disimpulkan bahwa $\mathrm{H}_{0}$ diterima yang berarti nilai rata-rata pretest kelas eksperimen sama dengan nilai rata-rata pretest kelas kontrol.

\section{Analisa Tahap Akhir}

\section{Uji Normalitas}

Dari hasil output SPSS diperoleh nilai signifikasnsi untuk kelas ekaperimen adalah 0,176 dan kelas kontrol adalah 0.200. 
Karena nilai signifikasi kelas eksperimen dan kelas kontrol mas-

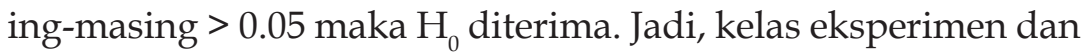
kelas kontrol berdistribusi normal.

\section{Uji Homogenitas}

Berdasarkan data output SPSS untuk uji homogenitas diperoleh nilai signifikansi (sig.) 0.960. Nilai tersebut $>0.05$ maka $\mathrm{H}_{0}$ diterima. Hal ini berarti kedua kelas sampel mempunyai varians yang sama.

\section{Uji Linearitas Hubungan}

Hasil output SPSS menunjukkan bahwa nilai Pearson Correlation antara nilai pretest (variabel kovarian) dan nilai hasil belajar/posttest (variabel terikat) adalah 0,574 dengan nilai signifikansi (Sig. 2-tailed) adalah 0.000. Karena nilai Sig < 0,05 maka $\mathrm{H}_{1}$ diterima yang berarti ada korelasi antara pretest dan posttest/ hasil belajar.

\section{Uji ANCOVA}

ANCOVA dilakukan dengan menambahkan variabel kovariat (pretest) pada model ANOVA yang berelasi dengan variabel dependen (posttest/hasil belajar). Penambahan ini bertujuan mengurangi variansi kesalahan (error) dalam model.

Uji ANCOVA dilakukan menggunakan SPSS. Dari hasil pengolahan data terlihat bahwa angka signifikansi untuk peubah media adalah 0,001. Karena nilainya jauh di bawah 0,05 maka $\mathrm{H}_{0}$ ditolak. Sehingga dapat disimpulkan bahwa pada tingkat kepercayaan $95 \%$ ada pengaruh penggunaan media animasi terhadap nilai posttest (hasil belajar) yang diperoleh mahasiswa. Hal ini berarti penggunaan media animasi memberikan pengaruh yang signifikan dalam meningkatkan hasil belajar trigonometri mahasiswa tadris matematika IAIN Walisongo Semarang.

\section{Pembahasan}

Hasil penelitian ini menunjukkan pentingnya penggunaan media dalam proses pembelajaran, termasuk pembelajaran trigonometri. Media secara tidak langsung dapat dijadikan sebagai skenario yang mengarahkan jalannya proses belajar dan pembelajaran. Salah satu media yang dapat digunakan dalam pembelajaran trigonome- 
tri adalah media animasi. Media animasi merupakan media pembelajaran berbentuk animasi yang menyerupai buku. Efek animasi pada media animasi membuat media tersebut menjadi lebih menarik sehingga mampu menarik perhatian mahasiswa. Dengan media animasi ini perhatian mahasiswa menjadi lebih terfokus pada materi yang disampaikan oleh dosen. Pemanfaatan media animasi dalam pembelajaran dapat membangkitkan keinginan, minat, serta meningkatkan motivasi mahasiswa.

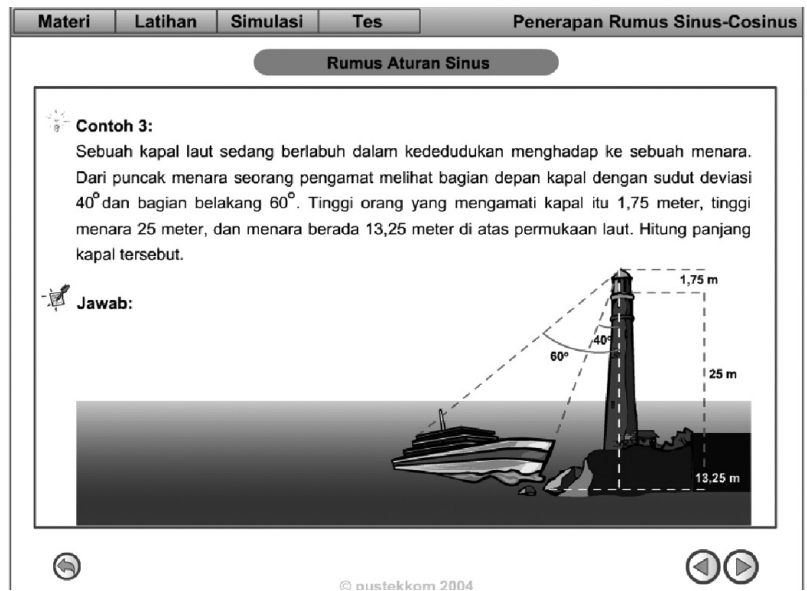

Gambar 1. Animasi dalam Media Pembelajaran Trigonometri (Sumber : Salimyes, 2009)

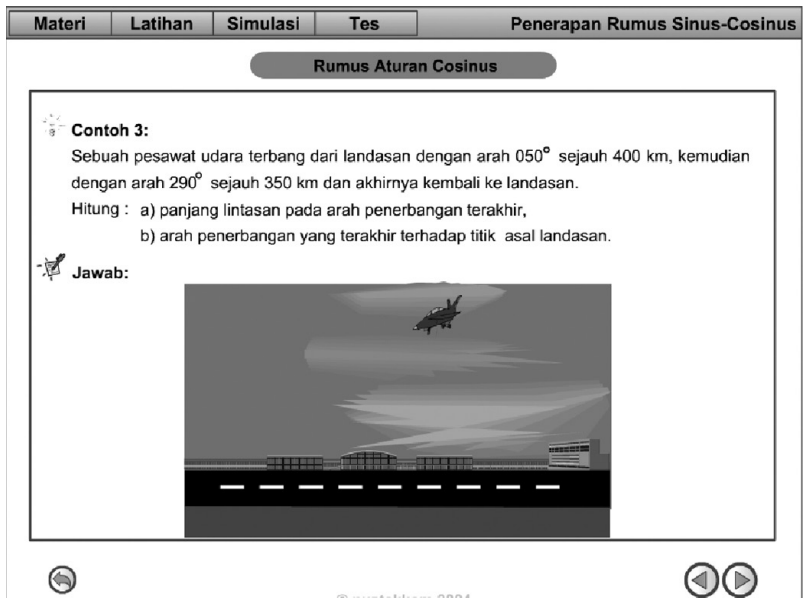

Gambar 2. Animasi dalam Media Pembelajaran Trigonometri (Sumber : Salimyes, 2009) 
Media animasi dapat meningkatkan kualitas pembelajaran. Penjelasan dosen tentang materi yang diajarkan tidak lagi hanya bersifat verbal tetapi juga dapat digambarkan dalam bentu animasi yang menarik. Selain itu, media animasi juga mampu menjelaskan hal-hal yang bersifat abstrak menjadi lebih konkret. Banyak mahasiswa yang kesulitan dalam menyelesaikan soal-soal cerita yang bersifat abstrak, dalam hal ini soal-soal yang membutuhkan visualisasi yang jelas. Kesulitan mahasiswa adalah membahasakan soal cerita tersebut ke dalam skema gambar dan mengubahnya ke dalam bentuk bahasa matematika. Soal-soal yang bersifat abstrak tersebut dapat digambarkan dengan baik oleh media animasi dalam bentuk animasi yang bergerak. Melalui animasi tersebut soal yang bersifat abstrak menjadi lebih konkret dan mudah dipahami mahasiswa sehingga mahasiswa dapat menggambarkan soal dalam skema segitiga. Setelah itu, mahasiswa dapat menentukan apakah penyelesaian soal tersebut menggunakan aturan sinus, aturan cosinus, atau menentukan luas segitiga. Melalui penggunaan media animasi, mahasiswa dapat memahami materi dan soal dengan lebih mudah, memperkuat ingatan serta dapat memberikan hubungan antara isi materi pelajaran dengan dunia nyata.

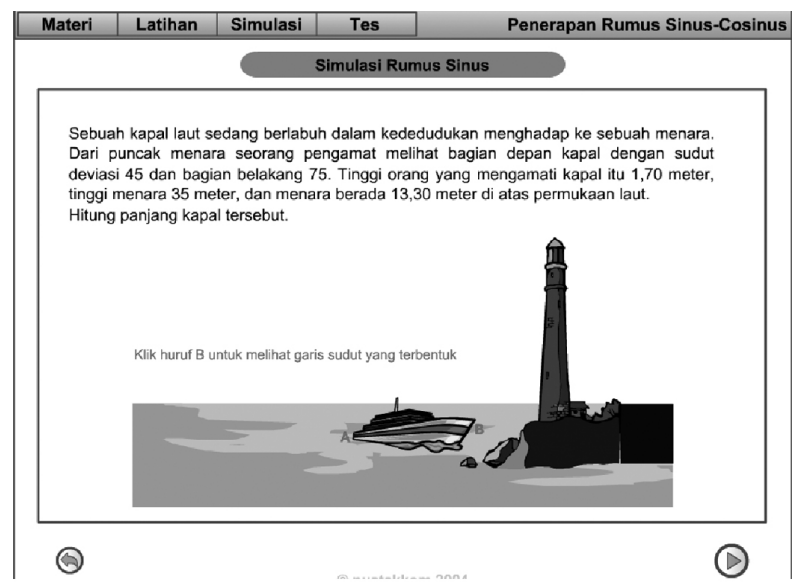

Gambar 3. Flip Book Memvisualisasikan Soal Menjadi Lebih Konkret (Sumber : Salimyes, 2009) 


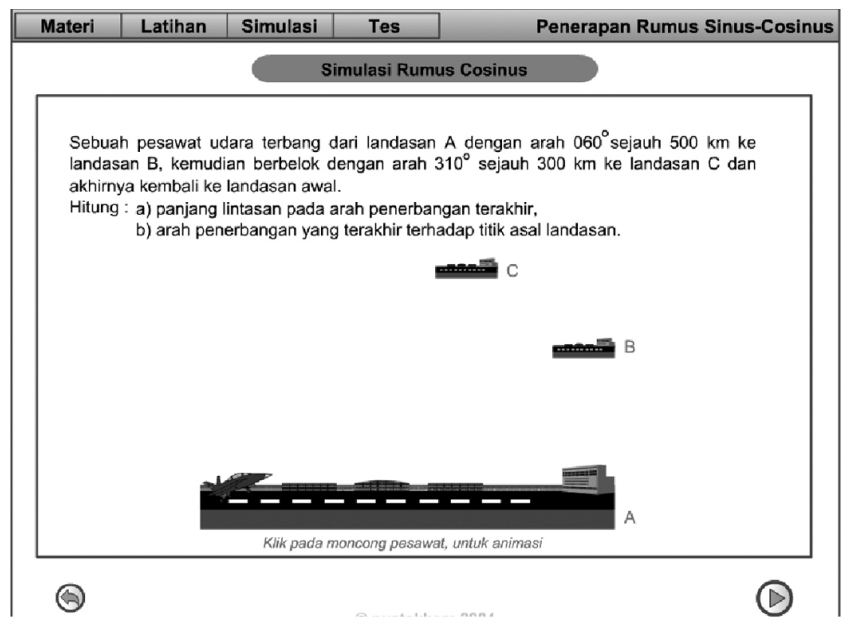

Gambar 4. Flip Book Memvisualisasikan Soal Menjadi Lebih Konkret (Sumber : Salimyes, 2009)

Penggunaan media animasi dengan penyajian yang variatif dan menarik mampu memberikan pengalaman belajar alternatif untuk menarik perhatian mahasiswa dan membuat pembelajaran trigonometri menjadi lebih mengasyikkan sehingga mahasiswa menjadi tidak bosan dan tidak bersikap pasif. Mahasiswa jadi menyukai mata kuliah trigonometri yang mempunyai rumus-rumus yang banyak dan tahu bagaimana penerapan rumus-rumus tersebut dalam kehidupan sehari-hari.

Banyak manfaat yang diperoleh dosen maupun mahasiswa melalui penerapan media animasi dalam pembelajaran. Proses belajar mengajar menjadi efektif dan efisien. Penerapan media animasi dalam pembelajaran membuat mahasiswa menjadi tertarik dan termotivasi dalam mempelajari materi trigonometri sehingga mahasiswa tidak bosan, tidak bersikap pasif, dan berkonsentrasi kepada isi pelajaran. Proses belajar mengajar menjadi lebih mengasyikkan dan metode yang digunakan dosen lebih bervariasi. Penggunaan media animasi mampu merangsang kegiatan belajar mahasiswa, membantu keefektifan proses pembelajaran, memperlancar pencapaian tujuan untuk memahami dan mengingat informasi yang diberikan. Selain itu, penggunaan media animasi juga dapat menjelaskan materi yang bersifat abstrak menjadi konkret sehingga 
membantu mahasiswa dalam memahami materi segitiga. Hal ini berakibat pada meningkatnya hasil belajar mahasiswa pada kelas yang pembelajarannya menggunakan media animasi. Jadi, dapat disimpulkan bahwa penggunaan media animasi dapat meningkatkan hasil belajar mahasiswa Tadris Matematika IAIN Walisongo Semarang.

\section{SIMPULAN}

Dari hasil penelitian yang telah dilakukan maka dapat disimpulkan bahwa ada pengaruh penggunaan media animasi terhadap nilai posttest (hasil belajar mahasiswa). Dengan kata lain penggunaan media animasi memberikan pengaruh yang signifikan dalam meningkatkan hasil belajar trigonometri mahasiswa tadris matematika IAIN Walisongo Semarang. Hal ini berdasarkan nilai signifikansi peubah media pada uji ANCOVA yang bernilai 0.001. Nilai tersebut lebih kecil dari 0.05 sehingga $\mathrm{H}_{0}$ yang menyatakan bahwa tidak ada pengaruh penggunaan media animasi terhadap nilai posttest/hasil belajar mahasiswa ditolak.

\section{UCAPAN TERIMA KASIH}

Terima kasih kepada seluruh mahasiswa matematika terutama mahasiswa semester II yang telah menjadi objek penelitian ini. Terima kasih atas kerja samanya sehingga penelitian ini dapat terlaksana. 


\section{DAFTAR PUSTAKA}

Arikunto, Suharsimi. 2010. Prosedur Penelitian Suatu Pendekatan Praktek. Jakarta : Rineka Cipta.

Ginting, Abdurahman. 2007. Esensi Praktis Belajar dan Pembelajaran. Bandung : Humaniora.

Latuheru, John D. 1988. Media Pembelajaran dalam Proses Belajar Mengajar Masa Kini. Jakarta : Departemen Pendidikan dan Kebudayaan.

Nasution, S. 2003. Metode Research. Jakarta : Bumi Aksara.

Sadiman, A. S. dkk. 1996. Media Pendidikan : Pengertian, Pengembangan, dan Pemanfaatannya. Jakarta : PT. Raya Grafindo Persada.

Salimyes. Download Media Pembelajaran Matematika Berbasis Macromedia Flash. [Online]. (salimyes.blogspot. com/2009/06/download-media-pembelajaran-matematika.html). Diakses pada tanggal 25 Maret 2013.

Sudjana, Nana dan A. Riva'i. 2011. Media Pengajaran. Bandung: Sinar Baru Algesindo.

Sudjana, Nana dan Ibrahim. 1989. Penelitian dan Penilaian Pendidikan. Bandung : Sinar Baru Algesindo.

Susilana, Rudy dan Riyana, Cepy. 2008. Media Pembelajaran; Hakikat, Pengembangan, Pemanfaatan, dan Penilaian. Bandung : Jurusan Kurikulum dan Teknologi Pendidikan-FIP-UPI.

Utami, D. 2007. Animasi dalam Pembelajaran. [Online]. (www. uny.ac.id/akademik/default.php). Diakses pada tanggal 13 Februari 2013. 